\title{
Application of Landsat 8 Imagery for Potential of Groundwater Mapping in Bogowonto Downstream Watershed, Purworejo Regency
}

\author{
Sudaryatno \\ Lecturer in Department of Geography Information Science \\ Universitas Gadjah Mada \\ Yogyakarta, Indonesia \\ Corresponding email: sudaryatno@ugm.ac.id \\ Rifqi Fathurrahman \\ Student in Department of Geography Information Science \\ Universitas Gadjah Mada \\ Yogyakarta, Indonesia \\ Dessy Ayu Wijayanti \\ Student in Department of Geography Information Science \\ Universitas Gadjah Mada \\ Yogyakarta, Indonesia
}

\begin{abstract}
Groundwater is a vital source of water for the needs of human, animals, and plants, not least in Bogowonto Downstream Watershed, Purworejo Regency. Bogowonto Downstream Watershed is a region which near with international airport development planning in Temon District, Kulonprogo Regency, Special Region of Yogyakarta. Along with this international airport development planning is absolutely necessary studies about the use of groundwater allocations in support of the region development. This research uses Remote Sensing and Geographic Information System (GIS) technologies to make groundwater potential mapping. The imagery which used in this research is Landsat 8 imagery to interpret land parameters, such as rock type, landform, lineament, soil texture, and landcover. The other datas which used in this research is Geology Map, Rupabumi Indonesia Map (Topographic Map), and Soil Map as references of identification. The method used in this research was scoring method in which each parameters rated in accordance with the effect of the groundwater potential resulting land unit for analysis of groundwater potential. The result from this research are groundwater potential map distribution in Bogowonto Downstream Watershed, precisely in Bagelen, Purwodadi, and Ngombol Districts. The higher potential of groundwater located in flat area, which is in Districts of Purwodadi, Bagelen, and Ngombol. The medium potential of groundwater located in coastal area, which is in Districts of Puwodadi and Ngombol. The lower potential of groundwater located in hilly area, District Bagelen.
\end{abstract}

Keywords-Potential of groundwater, Remote Sensing, Geographic Information System.

\section{INTRODUCTION}

Hydrological cycle of falling rainwater on earth surface will go through several processes. Partly rain water will go through infiltration process, fill the soil pores, and flow by gravity towards to the lower topography and then to the sea.
The hydrological cycle also contains several processes, these are evaporation and interflow, but most will be stored as groundwater.

Groundwater is the water that was in saturated layer below the soil surface (Pohl, C. 1998). Groundwater is a very important source of water for the various needs because it has a large quantity and the quality was pretty good. From the literature history of the development areas in various parts of the world indicates that groundwater is one of the most important water source in the social and economic life of the community. Groundwater has influence significantly to various aspects of the world, such as: transport, trade and other economic activities, interaction between nations, and also geographic expansion. The existence of groundwater is not affected by the seasons so that it can be obtained in the dry season, although with a reduced discharge. Fluctuation of groundwater during the rainy season will create spring in some places because of high groundwater level rises and contact with the ground.

The utilization of groundwater in industrial environments, residential, modern agriculture, and other human activities that require large amounts of water generally utilize wells to supply the water needs. Groundwater management system arranged that the groundwater extraction process will always be adjusted to their needs. At the level of such management requires the availability of groundwater data along with the pattern changes and its dynamics. Therefore, the availability of groundwater needs to be mapped for further use planning without disturbing the ecological function (Asdak, C. 2014).

Discourse about displacement of Adisucipto International Airport in Maguwoharjo, Sleman to Temon, Kulon Progo 
Regency have surfaced in recent years. Reason to move the location of the airport is due to existing airports currently not able to accommodate the number of passengers and flights in the regional and international scale in large quantities. Related to that issue needs to be planned and considered the carrying capacity of the region, especially the availability of adequate amounts of clean water to anticipate a large scale development activities such as the growth of trade centers and new accommodation. Bogowonto Downstream Watershed, which includes District Bagelen, District Purwodadi, and District Ngombol is a region that directly intersect with the center of the new growth, so that in these three areas need to recognize the potential of groundwater in supporting the development of the airport area.

Information related to the availability of groundwater can be obtained through the field survey and through remote sensing technology. Field survey has a good degree of accuracy, but costs a lot, a great power, and needs a relatively long time, so that need an alternative effective and efficient method through remote sensing technology. Remote sensing technique can provide a geo-related information that is representative to the cost, effort, and time effective, thus tapping the data in the field can be done to a minimum.

One way to determine the potential of groundwater is using remote sensing imagery and geographic information systems. Remote sensing imagery can be used to tap the information about landscape for the identification of hydrology. Remote sensing technology also helps a lot in the observation of a phenomenon that is hard to do with the naked eye. One of the remote sensing product that still relatively new is the Landsat 8. Landsat 8 is a resource satellite that has a spatial resolution of 30 meters. The availability of image data time series is one of the advantage by the Landsat 8 . Through these advantage, Landsat 8 can be utilized in various sectors, one is hydrology sector. The ability of Geographic Information Systems (GIS) such as the ability to store and manipulate geographic information and the ability to overlaying between multiple parameters, can be used to estimate the potential of groundwater.

Therefore, this study aimed to assess the ability of remote sensing imagery in land use parameter extraction for potential of groundwater mapping in Bogowonto Downstream Watershed, Purworejo Regency and mapping the potential of groundwater in Bogowonto Downstream Watershed, Purworejo Regency using Remote Sensing data and Geographic Information Systems help.

\section{METHOD}

\section{A. Geometric and Radiometric Correction}

Geometric correction is done to put back the position of the pixels imagery in the proper position, so that the image is recorded in accordance with actual conditions in the field. Pixel positions that not in right places be happening as a result of systematic error when recording the imagery. Geometric correction is done by using a reference RBI map scale of 1: 25,000 . Radiometric correction is done to make the value of existing pixels in the imagery correctly represent true reflection of the actual object. The correction is done by looking at the pixel values of the imagery histogram to adjust image pixel values with the appropriate value. This correction is very important to do because of image processing on the next stage will always be associated with the pixel value.

\section{B. Transformation of Vegetation Index (NDVI)}

The transformation of the vegetation index is an attempt to change the image pixel value in order to produce images with new pixel value that represents the variation of vegetation. Transformation of vegetation indices used in this study is the Normalized Difference Vegetation Index (NDVI). This transformation is based on the consideration of the red and near-infrared bands, wherein the second band have high contrast on the value of the vegetation. The resulting NDVI range value between -1 and +1 . The equation used to Normalized Difference Vegetation Index (NDVI) is:

$$
\frac{\text { Near Infrared Band-Red Band }}{\text { Near Infrared Band+Red Band }}
$$

\section{Lithology Parameter Extraction}

The lithology is one of the parameters that affect the characteristics of groundwater aquifers. The amount of influence of groundwater causes lithological characteristic has the highest weighting factor than other parameters. Lithology map scale of 1: 50,000 can be arranged through visual interpretation with the aid of Landsat 8 composite imagery and Central Java Geological Map scale of 1: 100,000.

Drainage patterns shown Landsat 8 composite 567 can help identify the level of violence rocks. Age of rock, the type of rock formations, and materials characteristics of the rock formations can be lowered through the Geological Map scale of 1: 100,000. The analysis about correlation between types of rock formations, rock formations age, and material characteristics of the rock formations with a specific landforms can provide more detailed physical information related to the existing rock.

\section{Slope Mapping}

The slope is required to analyze the landforms and used as one parameter determining the location of the springs. Slope map created using elevation data derived from RBI contour with contour interval of $12.5 \mathrm{~m}$. The contours can be converted into digital elevation data that showed relief and slope. Classification of relief using the classification of Van Zuidam in 1983 as shown in the table below:

TABLE 1: SLOPE CLASSIFICATION

\begin{tabular}{|c|c|c|}
\hline Nu & Slope (\%) & Description \\
\hline 1 & $0-8$ & flat \\
\hline 2 & $8-15$ & gently sloping \\
\hline 3 & $15-25$ & undulating \\
\hline 4 & $25-45$ & steep \\
\hline 5 & $>45$ & very steep \\
\hline \multicolumn{2}{|c|}{ Source: Van Zuidam (1983) } \\
\hline
\end{tabular}




\section{E. Landcover Mapping}

In this study the classification used is the land use classification based on the Indonesian National Standard of Bakosurtanal (now known as Badan Informasi Geospasial) that was published in 2010 .

TABLE 2: LANDCOVER CLASSIFICATION REFERENCE SCALE OF $1: 50,000$ OR 1:25,000

\begin{tabular}{|c|c|c|c|}
\hline Nu & Landcover Classification & $\mathbf{N u}$ & Landcover Classification \\
\hline \multicolumn{2}{|r|}{ Nonvegetated Area } & \multicolumn{2}{|r|}{ Vegetated Area } \\
\hline 1 & $\begin{array}{l}\text { Bare area } \\
\text { - } \quad \text { bare area at caldera } \\
\text { - } \quad \text { lava } \\
\text { - } \quad \text { sand beach } \\
\text { - } \quad \text { sandbanks } \\
\text { - } \quad \text { sand dunes }\end{array}$ & 1 & $\begin{array}{ll}\text { Agricultural land } \\
\text { - } & \text { irrigated paddy field } \\
- & \text { rainfed paddy field } \\
- & \text { tidal paddy field } \\
- & \text { lowland paddy field } \\
- & \text { polder } \\
- & \text { field } \\
- & \text { plantation } \\
- & \text { mixed plantation } \\
- & \text { mixed crops }\end{array}$ \\
\hline 2 & $\begin{array}{l}\text { Settlement and related } \\
\text { nonagricultural land } \\
\text { - } \quad \text { built area } \\
\text { - } \quad \text { non-built area }\end{array}$ & 2 & $\begin{array}{l}\text { Non-agricultural land } \\
\text { - } \quad \text { forest wetlands } \\
\text { - } \text { forest drylands } \\
\text { - } \quad \text { grove } \\
\text { - } \quad \text { bush } \\
\text { - } \quad \text { meadow } \\
\text { - } \quad \text { savanna } \\
\text { - } \quad \text { grasslands } \\
\text { - } \quad \text { marsh grass }\end{array}$ \\
\hline 3 & \begin{tabular}{ll}
\multicolumn{2}{l}{ water } \\
- & lake \\
- & fishpond \\
- & salt pond \\
- & swamp \\
- & river \\
- & irrigation channels \\
- & coral reefs \\
- & sandbar
\end{tabular} & & \\
\hline
\end{tabular}

Source: Indonesian National Standard (2010)

\section{F. Landform Mapping}

Landform is formed on the surface of the earth as a result of changes in shape of the Earth's surface by geomorphological processes on the earth's surface. There are three criteria that must be considered in the interpretation of landforms, namely the relief or shape criteria, density criteria and location criteria.
There are five main things that become the basis for the interpretation of landforms using aerial photos or imageries, namely: topography, flow patterns, hue or color, land cover or land use, and the characteristics of the soil or rock Landsat 8 (L8). Landform map-making based on visual interpretation with the help of a geological map scale of 1: 100,000, soil maps scale of 1: 250,000, flow patterns, slope maps and land use maps on study area. The classification used is based on the genesis, process and rocks as proposed (Suharsono, P. 1999).

TABLE 3: LANDFORM UNIT FOR GEOMORPHOLOGICAL MAP SCALE OF $1: 100,000$

\begin{tabular}{|c|c|}
\hline Denudational Landform (D) & $\begin{array}{c}\text { Volcanic Landform } \\
(\text { V) }\end{array}$ \\
\hline D1 eroded hills & V1 crater \\
\hline D2 eroded mountains & V2 volcanic cone \\
\hline D3 residual hills & V3 volcanic upper slope \\
\hline D4 isolated hills & V4 volcanic middle slope \\
\hline D5 nearly plain & V5 volcanic down slope \\
\hline D6 upraised nearly plain & V6 volcanic foot slope \\
\hline D7 foot slope & V7 volcanic footplain \\
\hline D8 pediment & V8 volcanic-fluvial plain \\
\hline D9 fan slope & V9 lava field \\
\hline D10 rock mass land & V10 lahar field \\
\hline \multirow[t]{5}{*}{ D11 waste land } & V11 molten lava \\
\hline & V12 lava flow \\
\hline & V13 between volcanics plains \\
\hline & V14 plateau \\
\hline & V15 planese \\
\hline $\begin{array}{c}\text { Structural Landform } \\
\text { (S) }\end{array}$ & $\begin{array}{c}\text { Fluvial Landform } \\
\text { (F) }\end{array}$ \\
\hline S1 fault block & F1 alluvial plain \\
\hline S2 fault escarpment & $\mathrm{F} 2$ riverbed \\
\hline S3 fault escarpment line & F3 lake \\
\hline S4 anticlinal mountains & F4 swamp \\
\hline S5 anticlinal hills & F5 back swamp \\
\hline S6 sinklinal mountains & F6 dead river channel \\
\hline S7 sinklinal hills & F7 flood plain \\
\hline S8 monoclinal mountains & F8 natural levee \\
\hline S9 monoclinal hills & F9 river basin \\
\hline S10 dome mountains & F10 former lakebed \\
\hline S11 dome hills & F11 silt embankment \\
\hline S12 plateau & F12 sandbar \\
\hline S13 cuesta & F13 fluvial terrace \\
\hline S14 hogback & F14 alluvial fan \\
\hline S15 flat iron & F15 delta \\
\hline S16 anticlinal valley & F16 delta back \\
\hline S17 sinklinal valley & F17 delta basin \\
\hline S18 subsequent valley & F18 delta beach \\
\hline S19 horst & \\
\hline S20 graben & \\
\hline $\begin{array}{c}\text { Marine Landform } \\
\text { (M) }\end{array}$ & $\begin{array}{c}\text { Karst Landform } \\
(\mathrm{K})\end{array}$ \\
\hline M1 erosion waves yard & K1 karst plateau \\
\hline M2 steep cliff & K2 eroded karst hills \\
\hline M3 beach & K3 karst topographic \\
\hline M4 shoal beach & $\mathrm{K} 4$ residual and isolated hills \\
\hline M5 tombolo & K5 alluvial-karst plain \\
\hline M6 between beaches shoal & K6 karst valley \\
\hline M7 beach dunes & Glacial Landform \\
\hline M8 tidal flats & (G) \\
\hline M9 alluvial-marine plain & G1 glacial valley \\
\hline M10 alluvial-marine plain logged & G2 snow covered mountains \\
\hline M11 marine terrace & G3 glacial sediment plain \\
\hline $\begin{array}{l}\text { M12 coral reefs } \\
\text { M13 lagoon }\end{array}$ & $\begin{array}{c}\text { Aeolian Landform } \\
\text { (A) }\end{array}$ \\
\hline M14 marine sandbar & A1 sand dunes \\
\hline
\end{tabular}

Source: Suharsono (1999) 


\section{G. Lineament Mapping}

Lineament is one of the linear formations that can be seen from satellite imagery, aerial photography, and digital elevation models (Alejandro, M.2006). The linear formations may represent the morphological appearance of the anthropogenic formation (roads, irrigation, etc.), can also be a structural discontinuities of rock and other formations associated with tectonic activity. Lineament is generally placed in a valley, break of slope or ridgelines by Jordan on (Alejandro, M.2006). Interpretation of lineament pattern done visually using Landsat 8 which has a resolution of 30 meter.

\section{H. Field Unit Mapping}

Field associated with the physical properties of the earth's surface and similar in physical characteristics of the land, such as: climate, relief, geomorphological process, rocks and structures, soil and hydrology, while vegetation and land use is considered as indication factors. Map units are based on overlay between some maps, that is slope map, soil map, landform map, and landcover map.

\section{Field Sampling}

Determination of the samples was done by stratified random sampling method with sample locations are set in accordance with the field unit. Sampling serves to obtain validation and correction of distortion of the data processing resulted in the laboratory and the reality on the field.

\section{J. Field Check}

Field check used to checking of tentative maps about the physical factors of land so that the level of accuracy of the map can be known. Field check for samples taken at each mapping units. Sampling test on each polygon unit of land in the field consist of sample of landform, rock type, soil type, slope, soil texture, and landcover. The results of these checks then used as a reference for the reinterpretation of the tentative maps.

\section{K. Reinterpretation of the Tentative Maps}

The tentative maps of the results of the prefield is reinterpretation based on field datas by completing and correcting wrong information from the results of the initial interpretation.

\section{Accuracy Test of the Interpretation Result}

Accuracy test method using independent data sources that are never used in sampling so logically the value is truth and acceptable (Danoedoro, P. 2012). Map reclassifications of each physical factor is overlayed with existing independent data. Previously, the data are conditioned by each independent physical factors so that it can be compared pixel by pixel between the reference data (independent data) with the results of the classification error matrix using a table (Figure 1). This table considering the accuracy of the manufacturer (producer) and map users.

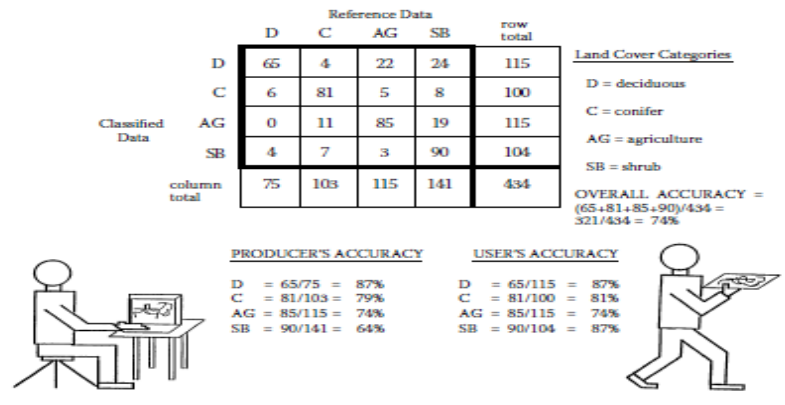

Fig. 1. The Example of the Table of Eroor Matrix

Source: Congalton et al (2009)

\section{Thematic Map}

Tentative map result from reinterpretation with the final independent data were then corrected so that the maps have a truth value in accordance with the conditions in field. This maps is the final result from the reinterpretation so that the maps have a good percentage of the truth and can be used to identify potential distribution of groundwater.

\section{N. Potential of Groundwater Map}

Potential distribution of groundwater map is a final map obtained through the steps using the overlay method of matching weight factor with several physical factors of land that determines the distribution of groundwater. Physical factors that is rock type map, landform map, slope map, soil type map, soil texture maps, and maps cover/land use. Expected output scale map is 1: 50,000. In determining the grade distribution of groundwater used reference table (Table 4). The table is made based on the elaboration of the theory and the results of previous studies associated with this research.

\section{FINDINGS AND DISCUSSION}

Water is a basic human, animals, and plants needs for life. One of the sources of water on this earth is groundwater. Potential of groundwater on earth vary according to the condition of the area. Physical parameters that affect the distribution of potential of groundwater include landform, lithology and soil, slope, pattern of the lineaments, and land cover/land use. Information on these parameters can be obtained using remote sensing technology.

\section{A. Landform Mapping}

Landforms can be used to view the distribution of the potential of groundwater in the Bogowonto Downstream Watershed, precisely in the District Bagelen, Purwodadi, and Ngombol. Landforms in this area is dominated by hills and plains. Incise hills in the eastern part consists of denudational hills with strong, moderate, and low eroded. While in the plains consists of landform that affected by volcanic process from Sumbing Volcanic Mountain, fluvial, and marine. In the plain areas have fluvial and fluvio-marin landforms. Strong eroded hills are shown in the level of surface roughness and the tapered ridges. District Bagelen dominated by hills, while the District Ngombol and Purwodadi currently on the flat 
topography. Of course, the flat area is a zone of accumulation of groundwater flow.

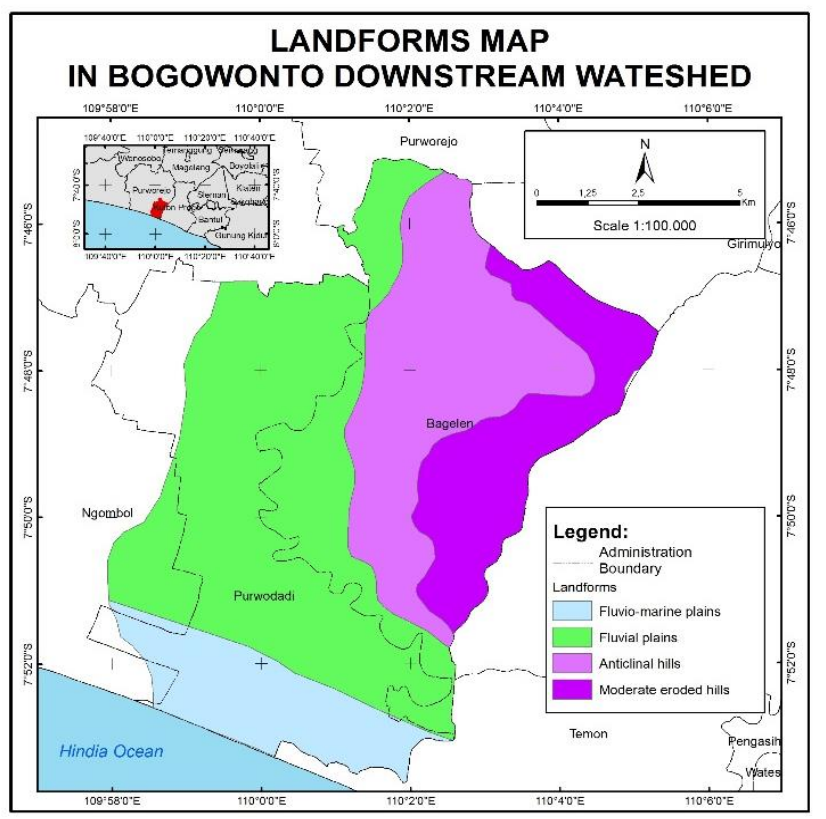

Fig. 2. Landforms Map in Bogowonto Downstream Watershed

\section{B. Lithology Mapping}

The rock formations that exist in the three districts is dominated by Tmok and $\mathrm{Qa}$ formations. Tmok formation contains andesite breccia, tuff, and agglomerate, while Qa formation contains gravel, sand, silt, and clay. These formations are formed by the age of tertiary and quarter. In a hilly area of Bagelen has formed over a long time at the age of tertiary and plain area in District Ngombol and Purwodadi formed at the age of quarter and continue to form until today. Quarter-lived rock has good permeability and good groundwater storage. Soil is formed already at the stage of sandy to clay and still processed continuously so that the particle is certainly more rugged. Thus it would be better permeability in charging groundwater. Qa formation (alluvium) that are in the plain area is the accumulation of water flow so that it is possible have a greater potential for groundwater than in mountainous areas.

Elements of rock that exist in these formations can be used to look at the soil approach. In plain areas dominated by sandy, silt, and clay. The soil characteristic will has a thick layer. Soil texture in the plain area is also smooth. In hilly area, the formation consist of andesite breccia, agglomerate, and andesitic lava rock. Soil formed is still at the stage of weathered rock so that the soil is thinner than the soil in plain areas.

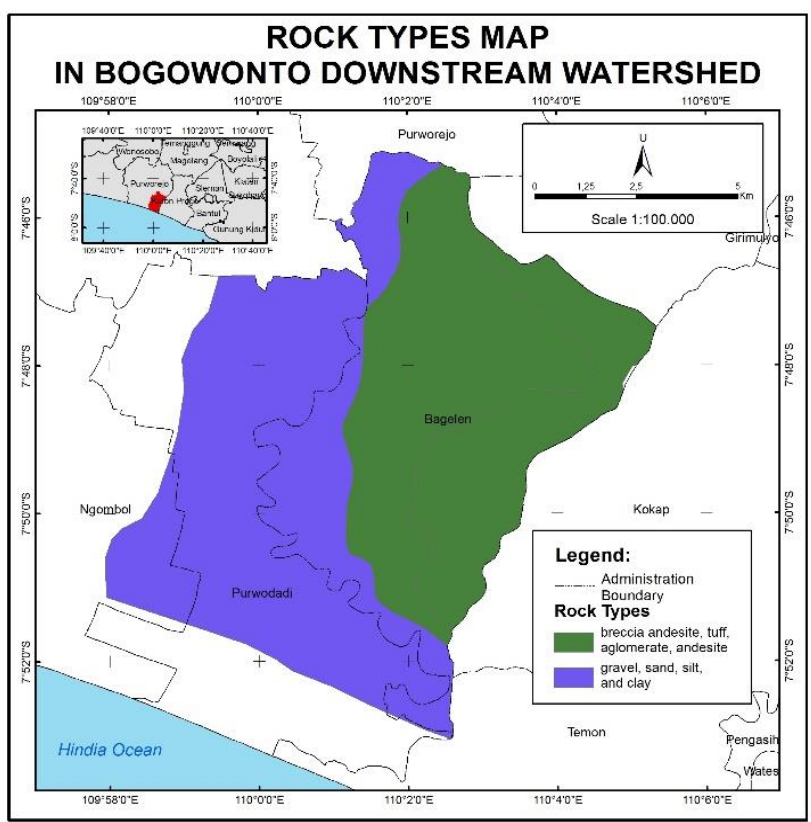

Fig. 3. Rock Types Map in Bogowonto Downstream Watershed

\section{Slope Mapping}

Slope created using ASTER GDEM imagery extraction. The imagery has a height information with a raster type. The imagery is extracted into the slope with the help of ArcGIS software. The classification made with a range of $0-8 \%$ (flat), $8-15 \%$ (gently sloping), $15-25 \%$ (undulating), $25-45 \%$ (steep), more than $45 \%$ (very steep). This classification has scores assuming that the steep terrain has the potential of groundwater smaller and more gentle slope, the potential for groundwater will be even greater.

Bogowonto Downstream Watershed study area is dominated by two classifications slopes, they are steep and flat areas. The hills in the District Bagelen has steep slope characteristic. But the District Ngombol and Purwodadi has flat slope. Flat area is the accumulation of water flowing from upstream areas. Upstream areas will be the catchment area to recharge groundwater. So on the plains there may be accumulation of water that is absorbed and groundwater are transported from the hills.

Figure 4 shows the boundaries between hilly and plain areas. The slope is not so drastic but there is change in the flat $(0-8 \%)$ and then becomes steep (15-40\%). Differences slope conditions would also affect the existing land use conditions. 


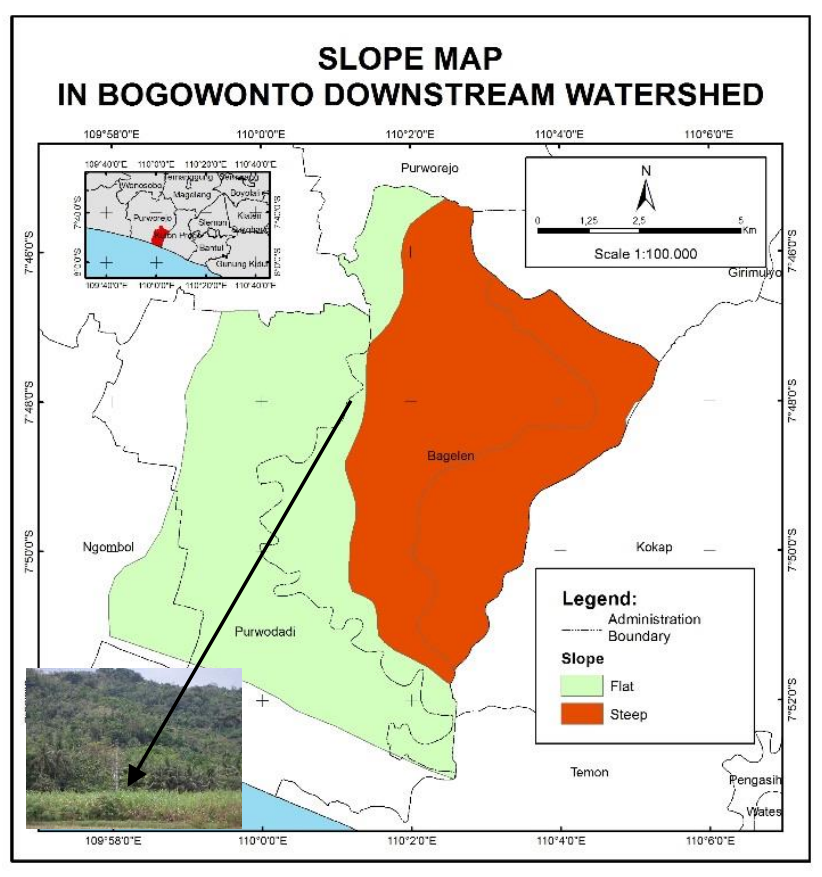

Fig. 4. Slope Map in Bogowonto Downstream Watershed

\section{Lineament Mapping}

Lineament patterns can be identified with the drastic changes slope. Lineament pattern can also be seen from ridges hills mainly on structural landforms. Their lineament also provide separate analysis on the availability of groundwater. Moreover lineament also be seen from the alignment of the flow pattern of the river. On the lineament patterns will allow the fracture so that water can recharge groundwater. Besides fractures also may be where the discharge of springs. On the slopes with a very steep slope conditions suddenly become the flat slope will be able to bring up the springs. Lineaments pattern which is the place for the springs as shown in Figure 5.

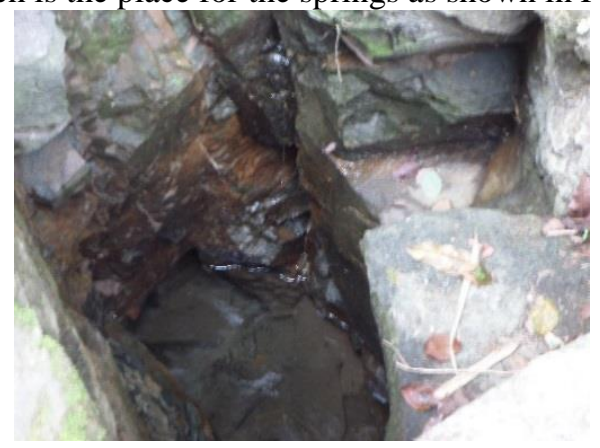

Fig. 5. Spring water in coordinate 395948 E, $9134920 \mathrm{~S}$

Basically, the lineament pattern has compact rock in it. When using the imagery will be visible the ridges with a tapered shape. On the ridge indicates the remainder of the process of denudation and rock solid. Compact eroded rocks would reflect the rest of the sharp ridges.

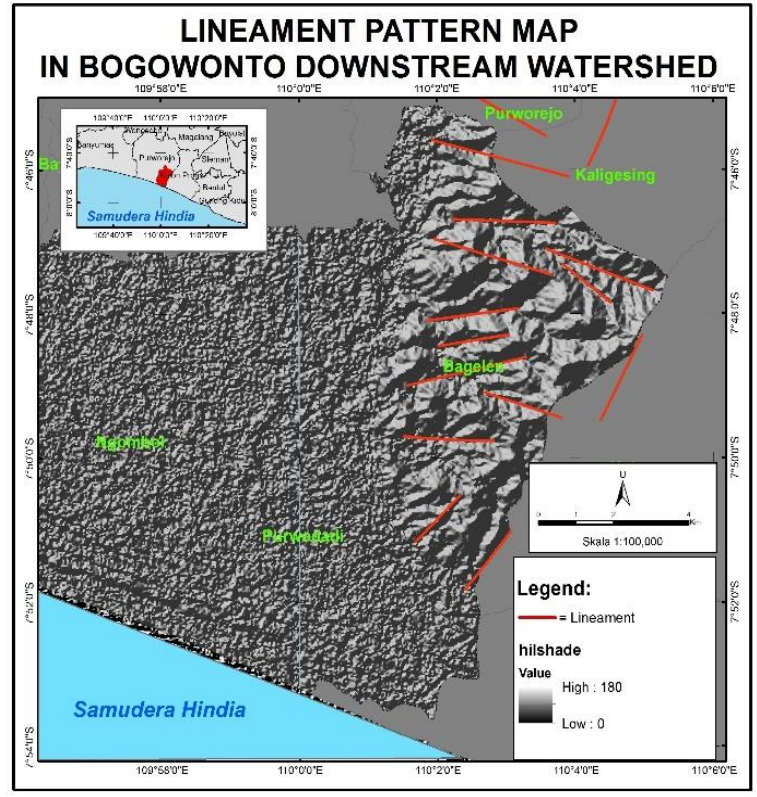

Fig. 6. Lineament Map in Bogowonto Downstream Watershed

\section{E. Landuse Mapping}

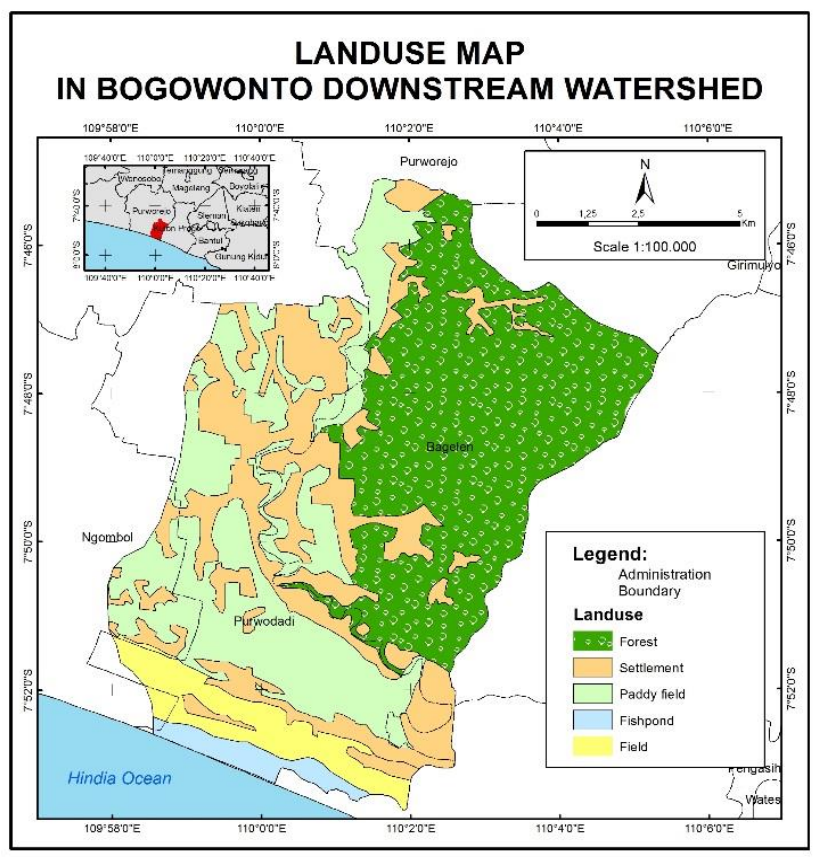

Fig. 7. Landuse Map in Bogowonto Downstream Watershed

The result of the interpretation shows that the Bogowonto Downstream Watershed has some dominant land use, settlements, paddy fields, fields, forests, and ponds. The settlements are common in relatively flat areas and little is found in the hilly areas in the eastern part of the watershed. Paddy field can be found in a flat area and is in the region around the settlements. Field can be found in almost all fluviomarine areas in the Bogowonto Downstream Watershed. Forests located in the eastern part of the Bogowonto 
Downstream Watershed because this region is a hilly area so it is more suitable when used as a forest. There are many ponds in coastal areas. The pond is located on the coast near the sea water so that the water supply to the pond continue to exist. Figure 8 shows the boundary between the plains to the hills where the image is visible changes in vegetation on the flat and mountainous areas.

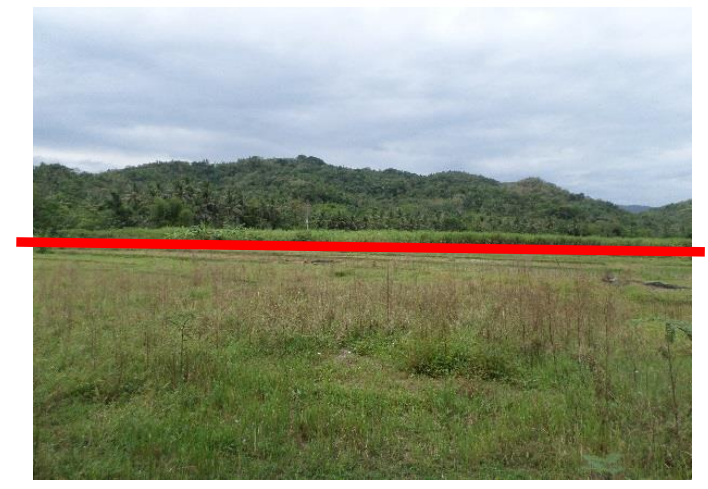

Fig. 8. Field photo in coordinate 392948 E, 9138320 S

The total accuracy for landuse interpretation checked with field data is $87.5 \%$. With this number, it can be said that the interpretation have been good and no need for reinterpretation. Table 4 shows the matrix accuracy for landuse.

TABLE 4: MATRIX ACCURACY FOR LANDUSE

\begin{tabular}{|c|c|c|c|c|c|c|c|}
\hline & \multicolumn{6}{|c|}{ Field data } & \multirow{2}{*}{$\begin{array}{l}\text { Over } \\
\text { all } \\
\text { row }\end{array}$} \\
\hline \multirow{6}{*}{ 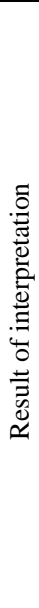 } & & $\begin{array}{l}\text { Settle- } \\
\text { ment }\end{array}$ & Forest & $\begin{array}{l}\text { Paddy } \\
\text { field }\end{array}$ & Field & $\begin{array}{l}\text { Fish- } \\
\text { pond }\end{array}$ & \\
\hline & $\begin{array}{l}\text { Settle- } \\
\text { ment }\end{array}$ & 10 & & & & & 10 \\
\hline & Forest & 3 & 9 & & & & 12 \\
\hline & $\begin{array}{l}\text { Paddy } \\
\text { field }\end{array}$ & & & 10 & & & 10 \\
\hline & Field & & & 2 & 4 & & 6 \\
\hline & $\begin{array}{l}\text { Fish- } \\
\text { pond }\end{array}$ & & & & & 2 & 2 \\
\hline \multicolumn{2}{|c|}{$\begin{array}{l}\text { Overall } \\
\text { colomn }\end{array}$} & 13 & 9 & 12 & 4 & 2 & 35 \\
\hline
\end{tabular}

$$
\begin{aligned}
\text { Overall accuracy } & =\frac{\text { the right object }}{\text { overail samples }} \\
& =\frac{35}{40} \\
& =87.5 \%
\end{aligned}
$$

\section{F. Potential of Groundwater Mapping}

The parameters used to determine the distribution of potential of groundwater is a factor of rock type, landform, slope, soil texture/type, lineament pattern, and land use. Each parameter has a different role in determining the distribution of potential of groundwater. The most dominant parameters that influence on the distribution of potential of groundwater is a rock type, soil texture/type, and lineament pattern. Rock type is very influential because of the rock type that is controlling the water can be passed or stored. One rock type that can pass water well is sandstone. Just as rock type, soil texture/type also affects the distribution of potential of groundwater. Soil that has a sandy texture easier to pass water while the clay texture is hard to pass the water. Lineament pattern greatly affect the distribution of potential of groundwater due to the number of lineament patterns in an area then the area is likely to have great potential of groundwater.

Landforms and slope parameters also affect the distribution of potential of groundwater although the effect is not as big as rock type, soil texture/type, and lineament pattern. Landforms become one of the parameters because landforms reflects the physical state of a region and also reflects the processes occurring in the area. Fluvial area is in a flat area so that the potential of groundwater in these areas is very high compared with other landforms. In terms of slope, flat slopes has great potential of groundwater while the steep slopes have very little potential of groundwater.

Parameters that have little effects on the distribution of potential of groundwater is landuse. However, the existence of this parameter can not be ignored. The landuse in an area will affect the distribution of potential of groundwater. Good land is land that can absorb rainwater to get into the soil and into groundwater resources. If the land is functioned in such a manner and the resulting water can not get into the soil, then the use of that land said to be not good in order to support their groundwater. The landuse that is not good is the settlements where the water can not get into the soil because it hampered the buildings standing on it. Good land is land planted with trees. Tree roots help water to get into the soil to become groundwater. The best landuse to support the entry of water is forest.

Based on linkage analysis of physical factors deciding distribution of potential of groundwater in the District Bagelen, Purwodadi, and Ngombol can be seen that the better potential of groundwater located in a flat area, which is in District Purwodadi, Ngombol and Bagelen. Moderate potential of groundwater were in coastal areas in District Ngombol and Purwodadi and in the hilly areas in the District Bagelen. Th worst potential of groundwater to be in most small hilly area in District Bagelen. The results obtained by scoring each of the physical parameters that affect the distribution of potential of groundwater. 


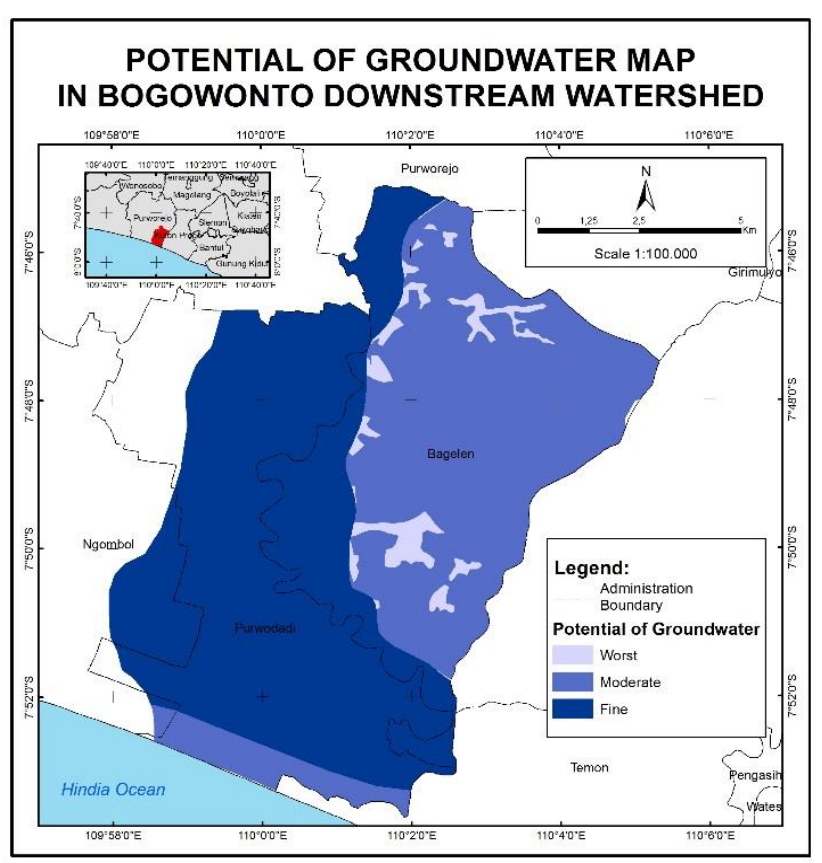

Fig. 9. Potntial of Groundwater Map

\section{G. Actual Condition}

Fieldwork was undertaken to determine the distribution of potential of groundwater in the District Ngombol, District Purwodadi, and District Bagelen. Distribution of groundwater sampling points are based on geomorphological conditions that exist in the three districts, especially in the hilly areas in District Bagelen and plains in District Purwodadi and Ngombol. There are 12 point that visited and provide information through the depth of wells. Distribution points are showing that in a hilly area has a very deep well with depth of 10-20 meters. The well depth take on the free aquifer. The confined aquifer's depth of 30-50 meters. Figure 10 shows the condition of the well in hilly areas.

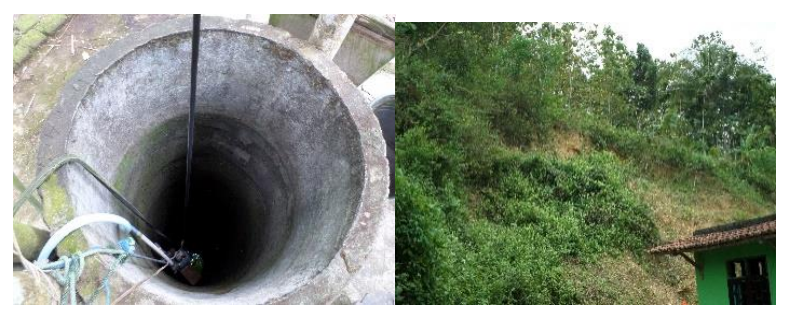

Fig. 10. The well's condition in hilly area

Flat area which is an area of the District Ngombol and the District Purwodadi has a depth shallower wells. The well on the flat area has a depth ranging from 5-10 meters. But sometimes the water is located on flat terrain dries up faster. When using deep wells that can reach depths of 20-35 meters while in dry season. Plain area is also dominated by paddy fields so that the water used for irrigation. At the point 8 coordinate X (387807 E) and Y (9139960 S) the well is 10 meters deeper than in other wells in the flat area that has a depth of 5-8 meters.

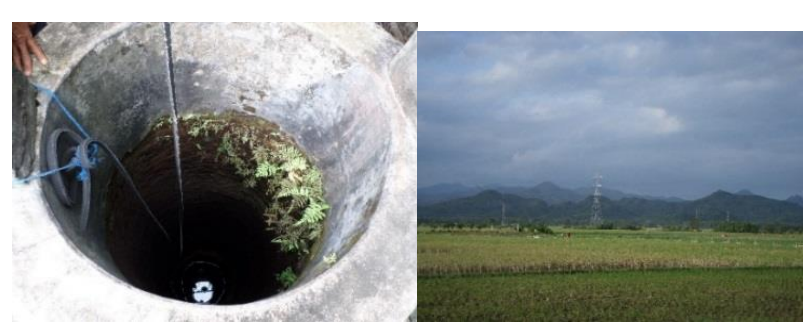

Fig. 11. The well's condition in plain area

Water tends to accumulate in areas adjacent to the river. In the valley area there are shallow wells (in the picture boxshaped well). The well is at the point 5 and point 7 . The two points close to the lineament.

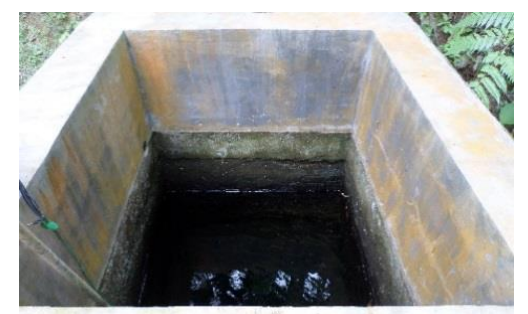

Fig. 12. The wells's condition around lineament area

\section{CONCLUSIONS}

- Landsat able to used to detect potential of groundwater parameters such as landuse, lineament pattern, landform, soil and slope. The land use accuracy rate of $87.5 \%$.

- The highest potential of groundwater is in District Purwodadi and Ngombol that can supporting the new airport development plan in District Temon, Kulonprogo, Special Region of Yogyakarta.

\section{REFERENCES}

[1] Alejandro, M.2006. Linement Extraction from Digital Terain Models (Case Study San Antonio del Sur Area South-Eastern Cuba). International institute for geo-information science and earth observation, enschede, the Netherlands

[2] Asdak, C. (2014). Hidrologi Dan Pengelolaan Daerah Aliran Sungai. Yogyakarta: Gadjah Mada University Press.

[3] Bemmelen, R.W.V. (1949). The Geology of Indonesia Vol. IA. The Hague: Government Printing Office.

[4] Congalton, R.G., and Green, K. (2009). Assessing the Accuracy of Remotely Sensed Data: Principles and Practices Second Edition. New York: CRC Press.

[5] Danoedoro, P. (2012). Pengantar Penginderaan Jauh Digital. Yogyakarta: C.V Andi Offset.

[6] Pohl, C. (1998). Multisensor Image Fusion in Remote Sensing: Concepts, Methods, and Application. International Journal of Remote Sensing Vol. 19, No. 5, page 823 - 854. Taylor and Francis Ltd.

[7] Suharsono, P. (1999). Diktat Kuliah Kode 12A: Identifikasi Bentuklahan dan Interpretasi Citra untuk Geomorfologi. Yogyakarta: Kerjasama Puspics Fakultas Geografi UGM dengan Badan Koordinasi Survei dan Pemetaan Nasional.

[8] Landsat 8 (L8) Data Users Handbook. Sioux Falls, South Dakota: EROS. 